\title{
Hacettepe Üniversitesi Illköğretim Bölümü Sınıf Öğretmenliği Anabilim Dalı Öğrencilerinin Düşünce Özgürlüğüne İlişkin
} Tutumları

\author{
Attitudes of Hacettepe University, Division of Primary \\ Education Students for Intellectual Freedom
}

Selda EKICI ve Bülent YILMAZ**

\begin{abstract}
Öz
Bu çalışma ile, ileride sınıf öğretmeni olarak görev yapacak öğretmen adaylarının düşünce özgürlüğü konusundaki yaklaşımlarını belirlemek amaçlanmıştır.

Çalışma kapsamında, Hacettepe Üniversitesi Eğitim Fakültesi Illköğretim Bölümü Sınıf Öğretmenliği Anabilim Dalı 4. sınıf lisans öğrencilerine anket uygulanmıştır. 100 öğrenciye uygulanan anket sonucuna göre, öğretmen adaylarının çoğu, üniversite eğitimine başlamadan önce düşünce özgürlüğü konusunda olumlu tutum geliştirmiş ve genel olarak aileleri ve çevreleri bu konuda olumlu katkı sunmuştur. Öğretmenlerin bu konudaki etkisi ise yeterli görülmemiştir. Üniversite eğitimleri sırasında düşünce özgürlüğ̈̈ konusunda kısmen bilinçlenmişlerdir. Illeride yetiştirecekleri öğrencilerin düşünce özgürlüğü konusundaki tutumlarına yapacakları etkinin öneminin farkında olmaları ise araştırmanın olumlu sonuçlarındandır.
\end{abstract}

Anahtar sözcükler: Düşünce Özgürlüğü, Sansür, Eğitim, Öğretmen, Tutum

\section{Abstract}

The aim of this research is to determine approaches to intellectual freedom of teachers in the future will serve as a classroom teacher.

A questionnaire was conducted to total of 100 students from Hacettepe University Elementary Education, Division of Primary Education 4th Grade Students. The results of the survey, most of teachers' has developed positive attitude to intellectual freedom and provided a positive contribution to their families and communities in general before university education but the impact of teachers is not adequate in this regard. The awareness of teacher candidates' intellectual freedom partially increased in the course ofuniversity education. One of the positive results is the study that they are aware of importancetheir impact on the students' attitudes about intellectual freedom in future.

Keywords: Intellectual Freedom, Censorship, Education, Teacher, Attitude

\footnotetext{
* Kütüphaneci, Orta Doğu Teknik Üniversitesi Kütüphanesi; Hacettepe Üniversitesi Bilgi ve Belge Yönetimi Bölümü yüksek lisans öğrencisi. (sekici@metu.edu.tr)

** Prof. Dr., Hacettepe Üniversitesi Bilgi ve Belge Yönetimi Bölümü öğretim üyesi. (byilmaz@hacettepe.edu.tr)
} 


\section{Giriş}

Bireylerin yaşantılarına yön veren yargıları, başka bireylerin de yaşantılarına yön verebilmekte ya da tutumlarına etki yapabilmektedir. Özellikle toplumda rol model olma sorumluluğu taşıyan ebeveyn, öğretmen gibi bireylerin bu konudaki etkileri daha fazla olmaktadır. Tutumlar ve yargılar, bireyin içine doğduğu ve ilk öğrenmelerini yaşadığı aile ile oluşmaya başlamakta, zamanla bireyin içinde yer aldığı toplumun kültürel özelliklerine, arkadaş çevresine ve eğitimine göre biçimlenmeye devam etmektedir. Düşünce özgürlüğü konusunda oluşturulan tutumlara aile, öğretmen, arkadaş çevresi, kültürel çevre gibi etmenler biçim verebilmektedir. Bu konuda bireylerin olumlu tutumlara sahip olabilmeleri için olumlu uyaranlarla karşılaşmaları son derece önemlidir. Yaşamın her evresinde hoşgörülü, demokratik, bilimsel düşüncenin olduğu ortamlar ve bireylerle karşılaşmak düşünce özgürlüğü konusunda olumlu tutumlara sahip olunmasını sağlayacaktır. Hoşgörüsüz, demokratik olmayan bireyler ve ortamlar ile karşılaşmak ise olumsuz tutum geliştirilmesine neden olabilmektedir. Bu noktada bireylerin eğitiminde ve öğretiminde görev yapan öğretmenlere büyük sorumluluklar düşmektedir. Düşünce özgürlüğü konusunda olumlu tutumlara sahip olan ve hoşgörü, demokrasi, bilimsel düşünce konularında iyi rol model olan öğretmenler, yetiştirecekleri öğrencilerin bu konudaki düşüncelerine olumlu katkı sağlayacaklardır.

Sınıf öğretmeni adayları üzerinde yapılan bu çalışmada, öğretmen adaylarının düşünce özgürlüğü konusundaki tutumları ile bu konudaki farkındalıkları belirlenmeye çalışılmıştır.

\section{Düşünce Özgürlüğü}

Düşünce ve özgürlük kavramlarının bileşiminden oluşan düşünce özgürlüğü, düşüncenin dış baskı ve yasaklarla sınırlandırılmaması (TDK, 2012) biçiminde tanımlanmaktadır. Sağlamtunç'a (1991, s.93) göre, "düşünce özgürlüğü insanın herhangi bir konuda istediği biçimde düşünme ve bu düşüncelerini istediği biçimde ifade edebilme hakkıdır." Değişik biçimlerde ifade edilen düşüncenin, diğer insanlara ulaşması ise düşünce özgürlüğünün bir başka boyutudur yani insanın bilgiye erişme hakkı da düşünce özgürlüğü kapsamındadır (Kızılkan, 1988, s. 159). Bu nedenle düşünce özgürlüğünün bir başka boyutu insanın bilgiye erişme hakkıdır. Gülle'ye $(1997$, s.18) göre, düşünce özgürlüğü, "düşüncenin oluşumundan bütün insanlara özgürce sunuluşuna kadar geçen süreci kapsayan ve bu özelliği ile evrensel olan en çağdaş iletişim yöntemidir. Bu çağdaş iletişim yönteminin sürecini oluşturan her birim (düşüncenin üretimi, dağıtımı, sunumu) ne kadar uyumlu ve sağlıklı olursa düşünce özgürlüğü de o denli amacına ulaşır." Tanımlardan yola çıkarak, düşünce özgürlüğünün kapsamını;

$\diamond$ İnsanın düşünme eyleminin engellenmemesi,

$\checkmark$ Düşünmenin ürünü olan düşüncenin yazı, resim, konuşma gibi değişik yollarla ifade edilmesi, açıklanması,

$\diamond$ Açıklanan düşünceye diğer insanların erişiminin engellenmemesi biçiminde özetleyebiliriz. 
Düşünce özgürlüğünü genişleyen bir döngüye benzetecek olursak; insanlar açıklanan düşüncelere erişecek yani bilgi edinecek, edindiği bilgiler sonucunda yeni bilgiler, düşünceler üretecek ve bu düşünceleri yayacaktır. Bu anlamda düşünce özgürlüğünün engellenmemesi toplumun gelişmişliğine ve büyümesine katkı sağlayacaktır.

Düşünce özgürlüğü ile ifade özgürlüğü içiçe geçmiş kavramlar olarak karşımıza çıkmaktadır. "Ifade özgürlüğü sözlü ve yazılı anlatım, sanatsal gösterim, kişisel görünüm ve görüntü tercihi, gösteri, yürüyüş, toplantı yapma ve örgütlenme gibi özgürlüklerin hepsini içine almaktadır"(Erdoğan, 2007, s.19). Çünkü dışa vurulmayan, ifade edilmeyen, herhangi bir yolla sunulmayan düşünceler koruma altındadır ve diğer insanların bu düşünceye erişim olanağı bulunmamaktadır. Ancak ifade edilen düşüncelere diğer insanların erişim olanağı bulunmaktadır. Düşünce özgürlüğünün oluşabilmesi için çoğulcu, serbest tartışmalı, hoşgörülü, demokratik, önyargıdan uzak ve tek doğrunun olmadığı özgür düşünme ortamı olmalıdır (Besimoğlu ve Korkut, 2011, s. 207).

Savaş'a (1995, s.7) göre, "düşünceyle demokrasi arasında sarmal bir ilişki bulunmaktadır. Düşünce yasaklandıkça demokrasi köklenemez. Demokrasi köklenemedikçe düşünce, özgürlüğüne kavuşamaz. Bu nedenle öncelikle demokrasinin tüm kurumlarda, tüm kurallarıyla ve tüm kavram genişliği ile toplumda temellendirilmesi gerekmektedir." Onaran'a (1995, s.10) göre, "demokrasi ile yönetilen toplumların temel ilkesi düşünce özgürlüğünün güvence altına alınmasıdır." Bu nedenle düşünce özgürlüğünün oluşabilmesi için okulların genç bireylere demokratik bir yaşamın sürdürülmesi için gereken ilke, tutum, değer ve uygulamaları öğretmesi son derece önemlidir. Bu öğretim sırasında en büyük görev öğretmenlere düşmektedir. Çünkü eğitim-öğretim sürecinde öğrencinin, öğretmenlerin tutumlarından, ilgilerinden, değerlerinden yalnızca bilgi düzeyinde değil tutum ve davranış düzeyinde de tüm kişiliğiyle etkilendiği görülmektedir (Ifflazoğlu ve Çaydaş, 2004, s.1).

\section{Düşünce Özgürlüğünün Yasal Boyutu}

Düşünce özgürlüğü, ifade özgürlüğü, inanç özgürlüğü gibi kavramlar bir takım yasal düzenlemeler ile koruma altına alınmaya çalışılmaktadır. Bunlardan bazıları şöyle özetlenebilir:

Birleşmiş Milletler Genel Kurulu tarafından 10 Aralık 1948' de ilan edilen İnsan Hakları Evrensel Bildirgesi'nde (BM, 1948), “Herkesin düşünce ve anlatım özgürlüğüne hakkı vardır. Bu hak düşüncelerinden dolayı rahatsız edilmemek, ülke sınırları söz konusu olmaksızın, bilgi ve düşünceleri her yoldan araştırmak, elde etmek ve yaymak hakkını gerekli kılar" ifadesi yer almaktadır. Bu Bildiri'nin, metninde açıklanan hakların her yerde ve etkin olarak tanınmasını ve uygulanmasını sağlamayı hedef alan ve 4 Kasım 1950'de yayınlanan "Avrupa Insan Hakları Sözleşmesi (AiHS)" nin 9. maddesinde düşünce, vicdan ve din özgürlüğü şu biçimde ifade edilmektedir: 
"Herkes düşünce, vicdan ve din özgürlüğüne sahiptir. Bu hak, din ve inanç değiştirme özgürlüğü ile açık veya özel biçimde ibadet, öğretim, uygulama ve tören yapmak suretiyle tek başına veya toplu olarak dinini ve inancını açıklamak özgürlüğü de içerir" (AïHS, 1950).

İfade özgürlüğü ise, AiHS'nin 10. maddesinde şu biçimde düzenlenmiştir:

"Herkes görüşlerini açıklama ve anlatım özgürlüğüne sahiptir. Bu hak, kanaat özgürlüğünü, kamu otoritelerinin müdahalesi ve ülke sınırları söz konusu olmaksızın haber veya fikir alma ve verme özgürlüğünü de içerir. Bu madde, devletlerin radyo, televizyon ve sinema işletmelerini bir izin rejimine bağlı tutmalarına engel değildir" (AïHS, 1950).

AiHS (1950) 'nin 9.ve 10. maddelerinde düzenlenen düşünce, vicdan, din ve ifade özgürlüğünün hangi durumlarda sınırlandırılacağı ise yine aynı maddelerin sonunda belirtilmiştir. Buna göre, belirtilen özgürlükler "demokratik bir toplumda ancak kamu güvenliğinin, kamu düzeninin, genel sağlığın ve ahlaki ya da başkalarının hak ve özgürlüklerinin korunması için gerekli olan tedbirlerle ve kanunla sınırlanabilir".

Türkiye'de düşünce özgürlüğü ile ilgili yasal düzenleme 1961 ve 1982 Anayasaları ile yapılmıştır. 1982 Anayasası'nın 25. maddesinde düzenlenen düşünce ve kanaat hürriyeti şu biçimde ifade edilmiştir: "Herkes, düşünce ve kanaat hürriyetine sahiptir. Her ne sebep ve amaçla olursa olsun kimse, düşünce ve kanaatlerini açıklamaya zorlanamaz; düşünce ve kanaatleri sebebiyle kınanamaz ve suçlanamaz" (TBMM, 1982). Anayasanın 26. maddesinde ise düşünceyi açıklama ve yayma hürriyeti düzenlenmiştir. Buna göre, "Herkes, düşünce ve kanaatlerini söz, yazı, resim veya başka yollarla tek başına veya toplu olarak açıklama ve yayma hakkına sahiptir" ancak maddenin sonunda bazı nedenlerden dolayı sınırlamalar olabileceği belirtilmektedir (TBMM, 1982). Bu özgürlüklerin kullanılmasına 1982 Anayasası ile getirilen sınırlılıklar 2001 tarihinde kabul edilen 4709 sayılı “Türkiye Cumhuriyeti Anayasası́nın Bazı Maddelerinin Değiştirilmesi Hakkında Kanun" ile yeniden düzenlenmiştir. Bu düzenlemeye göre, söz edilen özgürlüklerin kullanımı, "millî güvenlik, kamu düzeni, kamu güvenliği, Cumhuriyetin temel nitelikleri ve Devletin ülkesi ve milleti ile bölünmez bütünlüğünün korunması" amaçlarıyla sınırlanabilmektedir (TBMM, 2001). Yine Anayasanın 13. Maddesine göre, milli egemenliğin, cumhuriyetin, milli güvenliğin, kamu düzeninin, genel asayişin, kamu yararının, genel ahlakın, genel sağlığın korunması amacıyla Anayasa'daki bütün hak ve özgürlükler sınırlandırılabilmektedir (TBMM, 1982). Araslı (1995, s.23)'ya göre, hak ve özgürlükler hem özel nedenlerle hem de 13. Maddede yer alan nedenlerle sınırlandırılarak çift kilit altına alınmıştır. 


\section{Sansür}

Düşünce ve ifade özgürlüğünün engellenmesi sansürü doğurmaktadır. Sansür, "her türlü yayının, sinema ve tiyatro eserinin yayınının ve gösterilmesinin izne bağlı olması" (TDK Türkçe Sözlük, 2012) olarak tanımlanmaktadır. Bir başka tanıma göre sansür, "her türlü düşün ve sanat ürününün, siyaset, din, dil ve açık saçıklık açısından sakıncalı olduğu gerekçesi ile üretiminin, dağıtımının, ödünç verilmesinin veya satılmasının yasaklanması veya engellenmesidir" (Kızılkan, 1988, s.161). Sansür uygulayanlar, herkes için neyin iyi olduğunu kendilerinden başkasının bilmediğine inanan bireyler ya da gruplar olmaktadır (Sağlamtunç, 1991, s.95). Oysa ki her bireyin hassas olduğu konular farklıdır. Ortak noktalarda buluşabilmek ise demokrasinin bir gerekliliğidir. Ancak demokratik ortamlarda insanlar düşüncelerini ifade etme şansı bulabilirler.

Sansür ile düşünce özgürlüğünün sınırlarını birbirine karıştırmamak gerekir. Bir insanın düşüncelerine, inançlarına, hissettiklerine katılmamak demek o insanın düşüncelerine, inandıklarına, hissettiklerine küfretmek, hakaret etmek, alay etmek hakkını kimseye vermemektedir. Bu insan haklarına aykırı bir durumdur ve her birey diğerinin haklarına ve inançlarına saygıyla yükümlüdür. "Sansür, daha çok "kamu yararını koruma" gerekçesiyle devletin uyguladığı ön denetim, basım ve yayım yasağı olarak bilinir. Ancak, devlet dışındaki kişi, grup ve kuruluşlar tarafından, farklı gerekçelerle, düşünce ürünlerine uygulanan baskı ve engellemeler de sansür kapsamı içinde değerlendirilmektedir" (Besimoğlu ve Korkut, 2011, s. 212).

Bu araştırmanın da odaklandığı üzere öğretmenlerin düşünce özgürlüğü konusundaki tutumlarının yetiştirecekleri öğrencilerin düşünce özgürlüğü konusunda oluşturacakları tutumlara etkisi olacağı açıktır.

\section{Düşünce Özgürlüğü ve Tutum İlişkisi}

Düşüncenin özgür bir akış içinde sürebilmesi için özgür düşünen beyinlere ihtiyaç vardır. Özgür düşünen beyinlere sahip olabilmek için düşünmenin önündeki engelleri aşmak gerekmektedir. Engelleri aşmak ise, düşünmeyi etkileyen bilinç altı ve bilinç dışı, bedenden, ruhtan, kültürden ve dünya görüşünden gelen etkilerin bilincine varmak ile mümkün olabilmektedir (İnam, 1995, s.16). Üzerinde yeterince düşünmeden edindiğimiz kavramlar kadar içinde bulunduğumuz kültür özellikleri, yaşadığımız aile, aldığımız eğitim ve kişisel ilgi ve çabalarımız da zamanla tutumumuzu belirlemektedir.

Kağıtçıbaşı (2010, s. 109-110)'nın literatürde "klasikleşmiş” olduğunu ve günümüzde birçok sosyal psikolog tarafından kabul edilebileceğini belirttiği tanıma göre, tutum, "bir bireye atfedilen ve onun psikolojik bir obje ile ilgili düşünce, duygu ve davranışlarını düzenli biçimde oluşturan bir eğilimdir". Başka bir tanıma göre, "tutum, bireylerin belirli objelere karşı, geçirdiği çeşitli deneyimler sonucu düzenli bir tavır alışları, davranış biçimleridir" (AÖF, 2012). Tanımlara göre, tutum, doğrudan gözlenebilen bir özellik 
değil, bireyin gözlenebilen davranışlarından çıkarsama yapılarak o bireye atfedilen bir eğilimdir. İnceoğlu (2010, s.7), tutuma konu olabilecek somut ve soyut kavramları şu biçimde sıralamıştır; "bir eşya, bir tasarım, bir durum, bir olay ya da bir birey veya bireyler grubu tutumun konusu olabileceği gibi, herhangi soyut bir kavram, olgu ya da durum da mutluluk, mutsuzluk, iyi, kötü, tanrı vb. tutuma konu edilebilir" (İnceoğlu, 2010, s.7). Davranış bilimlerinin anahtar kavramlarından birinin tutum olduğu düşünülürse, tutumların insan davranışları üzerindeki etkisinin önemi ortadadır. Bir bireyin bir konudaki tutumunun davranışa dönüşebilmesi her zaman mümkün olmamaktadır. Bireyin tutumunun şiddeti, bireyin kendi tutum ve davranışlarının ne ölçüde farkında olduğu, zaman gibi etmenler tutumun davranışa dönüşebilmesinde veya dönüşmemesinde etkendir. Tutum ile davranışı ölçme arasında geçen zamanın uzunluğu ya da kısalığı tutum davranış ilişkisini etkilemektedir. Yine bireyin tutumunun şiddeti, davranış üzerinde etkilidir. Şiddeti ne kadar yüksekse davranışa dönüşme oranı o kadar yüksek olmaktadır (Kağıtçıbaşı, 2010, s.119-120).

\section{Tutumların Gelişmesi ve Kalıplaşması}

Bireylerin tutumlara sahip olarak doğmadıkları, tutumları sonradan öğrendikleri ve değişik etmenlerden etkilenerek geliştirdikleri bilinmektedir. Bu nedenle, öğretmenlerin düşünce özgürlüğü konusunda sahip oldukları tutumların, öğrencilerin düşünce özgürlüğü konusunda geliştirecekleri tutumlara etki edeceği söylenebilir. Tutumların gelişmesi ve kalıplaşması önemli bir konudur ve genelde, doğrudan deneyim, pekiştirme, taklit ve sosyal öğrenme gibi yollardan elde edilir (Kağıtçıbaşı, 2010, s.131-132).

Tutum oluşumu için duygusal, bilişsel, davranışsal ve toplumsal öğelerin varlığından söz edilebilir. Bu öğeler arasında güçlü bir ilişkiden söz edilmektedir. Özellikle duygusal öğelerin varlığı bilişsel öğeleri, yine bazı bilişsel öğelerin güçlü olması da duygusal öğeleri etkilemektedir. Bilişsel ve duygusal öğelerin varlığı her zaman davranış olarak karşımıza çıkmamakta ancak bilişsel ve duygusal öğelerin gözlemlenmesi de davranışlarla mümkün olabilmektedir. Bu öğelerden ilki duygusal öğelerdir. Bir olaya, nesneye ya da ürüne karşı olumlu, olumsuz ya da nötr duygular taşımak o olay, nesne ya da ürünle ilgili tutumumuzu belirleyecek bir etkendir. Bu olumlu, olumsuz ya da nötr duyguların oluşumunda arzu etme düzeyi, bireyin sahip olduğu değerler, aile ve bireyin hedefleri etkilidir. Tutum geliş̧iminin ikinci öğesi bilişsel öğelerdir. Bireyin bilgi düzeyi, inançları, düşünceleri tutum oluşumuna neden olan bilişsel öğelerdendir. Bilgilenme doğrudan etkileşim, deneyim ve kitle iletişim araçları aracılığıyla olmaktadır. Bir ürünle doğrudan deneyim yaşamak o ürün hakkındaki tutumumuzun oluşmasında etkilidir. Yine radyo, televizyon, kitap, gazete gibi kitle iletişim araçları ile edinilen bilgilerde tutum oluşumunda etkilidir. Tutum oluşumunda etkili diğer öğe, toplumsal öğelerdir. Kişilik gelişiminin temellerinin atıldığı çocukluk döneminde, çocuk ilk önce anne ve babası ile özdeşim kurmakta ve anne-babanın tutumlarını taklit yoluyla 
benimsemektedir (İnceoğlu, 2010, s.20). Yapılan araştırmalar, özellikle bireylerin kişilik ve benlik gelişimine farklı anne-baba tutumlarının etkisini ortaya koymaktadır (Bilal, 1984; Günalp, 2007; Yılmaz, 2009). Daha sonra arkadaş çevresi ve öğretmen tutumları bireyin tutum oluşturmasında etkili olmaktadır. Yani bireyin içine doğduğu ve büyüdüğü toplumsal yapı tutum oluşumunda önemli bir etkiye sahiptir. Yine bireyin bulunduğu kültürel ortam, aldığı eğitim ve ekonomik koşullar da tutum oluşumunu etkileyen diğer toplumsal öğelerdendir. Bir tutumun davranışa dönüştürülmesi durumunda ödüllendirilmesi, pekiştirmeye neden olmakta ve tutumun devamlılığını sağlamaktadır. Başkalarının dışa vurduğu tutumları benimseyerek kendi tutumumuz haline getirmemizde bir başka tutum geliştirme yoludur. Sosyal alanda oynanan roller sonucunda da değişik tutumlar geliştirmek söz konusudur. Bireylerde tutum oluşumuna etki eden önemli etkenlerden biri de medya, özellikle televizyondur (İnceoğlu, 2010, s.25).

Kalıplaşmış tutumlar da tutumun bir türüdür ve "bir bakıma belirli gruplar hakkında sahip olduğumuz bilgilerin bir özetidir" (Kağıtçıbaşı, 2010, s.133) biçiminde tanımlanabilir. Kalıplaşmış tutumlar da erken yaşlarda öğrenilmekte ve bu durumu değiştirecek önemli bir olay olmadığı sürece değişmemektedir.

\section{Tutum Oluşumunda Öğretmenin Rolü: Kuramsal Model}

Tutum oluşumuna neden olan ögeler içinde bireyin aldığı eğitim ve okul ortamı da yer almaktadır. Okulda öğrenilen tutumların, çocuğun gelecek yaşamına, kendi sorunlarıyla başa çıkmasına, ileri öğrenmelerini destekleyici yeni stratejiler geliştirmesine ve içinde yaşadığı topluma uyum sağlamasına önemli etkiler yapacağı unutulmamalıdır (Deniz, 2000, s.5). Bu nedenle, eğitim ve öğretim işlevini gerçekleştiren öğretmenlerin davranışları ile okul çocuklarının tutumlarına etki yapabileceği ve öğretmenlerin düşünce özgürlüğü konusundaki tutumlarının ve davranışlarının öğrencilerin düşünce özgürlüğü konusundaki tutumlarına ve davranışlarına yansıyacağı göz önünde bulundurulmalıdır. Gömleksiz (1988, s.11), eğitimin her kademesindeki öğretmenlerin, öğrencilerine hoşgörülü, haklara ve kişiliklere saygılı ve tutarlı demokratik davranışlar içine girerek rol model olması ve demokratik bireyler yetiştirmede öğretmen faktörünün öneminin farkında olması gerekliliğini vurgulamıştır. Düşünce özgürlüğünün demokratik ortamlarda geliştiği düşünüldüğünde, bağımsız, araştırmacı, iyi iliş̧kiler kurabilen, saygılı, hoşgörülü, özgür düşünebilen, daha iyilerini geliştirmek amacıyla eleştirebilen, demokratik öğrencilerin yetiştirilmesinde, öğretmenin rolü ve yapacağı rehberliğin önemi bir kez daha ortaya çıkmaktadır. Demirbolat (1999, s. 231) da çalışmasında, önce öğretmenlerin insan haklarına, farklılıkların kaçınılmazlığına, hoşgörüye, demokratik yaşam biçiminin güzelliğine inanması gerektiğini vurgulamaktadır.

Öğretmen adayları üzerinde yapılan çalışmanın kapsamı Şekil 1'deki model ile açıklanmaya çalışılmıştır. 


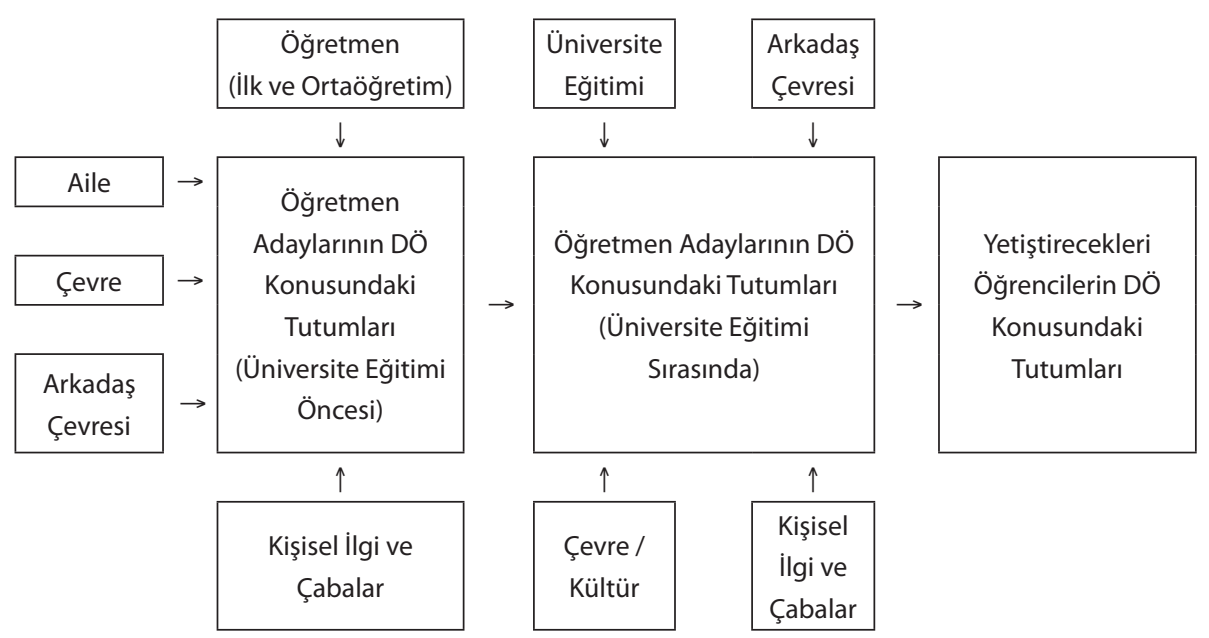

Şekil 1. Düşünce Özgürlüğüne (DÖ) illişkin Öğretmen Tutumlarının Oluşumu ve Bu Konuda Öğrenci Tutumlarına Etkisi

Öğretmen adaylarının düşünce özgürlüğü konusunda oluşturdukları tutuma, üniversite eğitimi öncesinde etki eden etmenler şu biçimde sıralanabilir: En başta aileleri daha sonra ilk ve ortaöğretim öğretmenleri ile içinde bulundukları çevre ve çevrenin kültürel yapısı. Bu dönemde düşünce özgürlüğü konusundaki tutumlarında arkadaş çevresi ile kişisel ilgi ve çabalarının da büyük etkisi bulunmaktadır. Öğretmen adayları, değişik kentlerden, çevreden ve kültürden gelerek üniversite eğitimine başlamaktadırlar. Üniversite eğitimleri sırasında düşünce özgürlüğü konusundaki tutumlarına etki edebilecek ve tutum değişikliğine neden olabilecek farklı bir çevre, arkadaş grubu, toplumsal ve kültürel etmenlerle karşı karşıya kalmaktadırlar. Üniversite eğitimi öncesinde oluşturdukları tutumlara üniversite eğitimi sırasında yeni tutumlar eklemekte ya da tutum değişimi yaşamaktadırlar. Eğitimleri süresince kazandıkları bu tutum ile öğretmen olarak göreve başladıklarında ise, rol model ve öğretici olma özellikleri ile yetiştirecekleri öğrencilerin düşünce özgürlüğü konusundaki tutumlarına etki edebilmektedirler.

\section{Araştırmanın Amacı, Kapsamı, Yöntemi}

Bu araştırmanın amacı, kuramsal çerçevede ele alınan model çerçevesinde ileride sınıf öğretmeni olarak görev yapacak öğretmen adaylarının düşünce özgürlüğü konusundaki yaklaşımlarını belirlemektir.

Çalışmanın evrenini Hacettepe Üniversitesi Eğitim Fakültesi İlköğretim Bölümü Sınıf Öğretmenliği Anabilim Dalı 4. sınıf lisans öğrencileri oluşturmaktadır. 4. Sınıf 
öğrencilerinin seçilme nedeni, üniversite eğitimini tamamlamak üzere olmaları ve düşünce özgürlüğü konusundaki tutumlarının netleşmiş olacağı düşüncesidir. Evreni oluşturan öğretmen adaylarının toplam sayısı 120'dir. Ulaşılabilen 100 öğrenciye anket uygulanmış ve sonuçlar değerlendirilmiştir. Araştırma 2012 Nisan ayında gerçekleştirilmiştir.

Araştırmada betimleme yöntemi kullanılmıştır. Veri toplama aracı olarak 28 sorudan oluşan anket kullanılmıştır. Can Besimoğlu ve Şelale Korkut tarafından hazırlanan "Siyaset Bilimi Öğrencilerinin Düşünce Özgürlüğü ile Illgili Görüşleri Anketi"nde yer alan 11 soru, öğretmen adaylarının düşünce özgürlüğü ile ilgili yaklaşımlarını belirlemek amacıyla araştırmamızda kullanılmıştır. Diğer 17 soru ise, öğretmen adaylarının düşünce özgürlüğü konusunda tutum oluştururken nelerden etkilendiğini belirlemeye yönelik sorulardır. Anket sonuçları SPSS 17 (Statistical Package for the Social Sciences) istatistik programı ile değerlendirilmiştir.

\section{Bulgular ve Değerlendirme}

Bu çalışmada, anket uygulanan öğretmen adaylarının ele alınan konudaki yaklaşımlarına ilişkin veriler sunulmuş ve yorumlanmıştır.

\section{Katılımcılara Ait Kişisel Bilgiler}

Ankete katılan öğretmen adaylarının toplam sayısı, 27'si erkek, 73'ü kadın olmak üzere 100 'dür. Öğretmen adaylarına yaşamlarını daha çok nerede geçirdikleri sorulmuş, \%58'i il, \%33'ü ilçe, \%9'u da köyde yanıtını vermişlerdir. Bu sonuca göre, ankete katılan öğretmen adaylarının yarıdan fazlası büyük şehirlerde yaşamış ve yaşamaya devam etmektedir.

Öğretmen adaylarının ebeveynlerinin eğitim durumlarına bakıldığında, babaların $\% 29^{\prime} u$ üniversite mezunu iken, annelerin sadece \%5'inin üniversite mezunu olduğu görülmektedir. Bu verilere göre, anne ile baba arasındaki eğitim farkı oldukça çarpıcıdır. Ankete katılan öğretmen adaylarının ebeveynlerinin büyük kısmı ilköğretim mezunudur.

\section{Öğretmen Adaylarının Düşünce Özgürlüğü Konusundaki Tutumlarına Etki Eden Etmenler}

Öğretmen adaylarının düşünce özgürlüğü ile ilgili oluşturdukları tutumların, ileride yetiştirecekleri öğrencilerin düşünce özgürlüğü konusundaki tutumlarına etki edeceği düşünülmektedir. Bireyde tutumların oluşmasında aile, öğretmen, çevre, arkadaş ve eğitim gibi etmenlerin önemli olduğu düşünülmüş ve öğretmen adaylarının bu konuda oluşturdukları tutumlara hangi etmenlerin ne ölçüde etki ettiği araştııımıştır. Bu etkiler, üniversite eğitimi öncesinde ve üniversite eğitimi sırasında olmak üzere iki biçimde sorgulanmıştır. 
Üniversite eğitimi öncesinde, öğretmen adaylarının düşünce özgürlüğü konusunda tutum oluşturmalarına etki eden etmenlerle ilgili veriler aşağıda (Tablo I) sunulmuştur.

Tablo I. Düşünce Özgürlüğü Konusunda Üniversite Eğitimi Öncesi Rol Oynayan Etmenler

\begin{tabular}{lrrrr}
\hline $\begin{array}{l}\text { DÖ konusunda fikir ve tutum oluşturmanızda } \\
\text { aşağıdakiler nasıl bir rol oynadı? }\end{array}$ & $\begin{array}{r}\text { Olumlu } \\
\text { Sayı-\% }\end{array}$ & $\begin{array}{r}\text { Olumsuz } \\
\text { Sayı-\% }\end{array}$ & $\begin{array}{r}\text { Etkili Olmadı } \\
\text { Sayı-\% }\end{array}$ & $\begin{array}{r}\text { Toplam } \\
\text { Sayı-\% }\end{array}$ \\
\hline Aile & 77 & 12 & 11 & 100 \\
Çevre & 57 & 23 & 20 & 100 \\
Arkadaş Çevresi & 52 & 15 & 33 & 100 \\
İlköğretim Öğretmeni & 34 & 29 & 37 & 100 \\
Ortaöğretim Öğretmeni & 31 & 32 & 37 & 100 \\
\hline
\end{tabular}

*Ankete katılan kişi sayısı 100 olduğu için bu ve bundan sonraki tablolarda sayı ve yüzde (\%) oranları aynıdır.

Kişilik gelişiminin temellerinin atıldığı ilk yer olan ailenin, tutum oluşumuna önemli etkileri vardır. Daha sonra bireyin içinde bulunduğu çevre ve diğer etmenler etkili olmaktadır. Ankete katılan öğretmen adaylarına düşünce özgürlüğü konusunda tutum oluşturmalarında ailelerinin ve içinde bulundukları çevrenin etkisi sorulduğunda, büyük çoğunluğu (\%77) ailelerinin olumlu etki yaptığını, yine yarıdan fazlası (\%57) çevrelerinin olumlu etki yaptığını ifade etmiş̧ir. Bireylerde tutum oluşumuna neden olan önemli toplumsal öğelerden biri de arkadaş çevresidir ve ankete katılan öğretmen adaylarının \%52'si düşünce özgürlüğü konusunda arkadaş çevresinin etkili olduğunu ifade etmiştir. Düşünce özgürlüğü konusunda tutum oluşturmada en yüksek olumsuz etkiye de ilk ve ortaöğretim öğretmenlerinin sahip olması dikkat çekicidir.

Özellikle ilköğretim öğretmenlerinin ve ortaöğretim öğretmenlerinin öğrencilerin kişilikleri üzerine etkileri bilinmektedir. Öğretmenlerin dışa vurdukları tutumları öğrencilerin tutumları haline gelebilmektedir. Bu nedenle ankete katılan öğretmen adaylarının düşünce özgürlüğü konusundaki tutumlarına kendi öğretmenlerinin etkisini araştırmakönemlidir.Öğretmen adaylarının sadece 1/3'ü düşünceözgürlüğü konusunda tutum geliştirmelerinde hem ilköğretim hem de ortaöğretim öğretmenlerinin etkili olduğunu ifade etmiştir. Olumsuz etki yapan ve etkili olmayan öğretmenlerin toplam oranı \%70'e yakındır. Bu veri, öğretmenlerin bu konudaki sorumluluklarının farkında olmadığını göstermektedir.

Bireylerin bir konu ile ilgili bilgilenmek amacıyla okuma yapması yani kişisel ilgileri ve merakları doğrultusunda okuması ve bu doğrultuda tutum geliştirmesi de mümkündür. Ankete katılan öğretmen adaylarımıza "İnsan hakları, düşünce özgürlüğü, ifade özgürlüğü vb." konularda okuyor musunuz? sorusu yöneltilmiş ve $\% 38$ evet, \%41 kısmen, \%21 hayır yanıtı alınmıştır. Beş öğretmen adayından birisinin sözü edilen konuda hiç okumamış olması, okuyanların oranının üçte birin biraz üzerinde olması da son derece olumsuz bir görünüme işaret etmektedir. 
Yöneltilen sorulara göre, öğretmen adayları üniversiteye gelmeden önce düşünce özgürlüğü konusunda aile, arkadaş ve çevrelerinden genellikle olumlu etkilenmiştir ancak bu konuda olumlu ya da olumsuz etki yapmayan öğretmenlerinin oranının yüksekliği öne çıkmıştır.

Öğretmen adaylarından, üniversiteye gelmeden önce düşünce özgürlüğü konusundaki tutumlarını genel olarak tanımlamaları istenmiş, bunu \%76'sı olumlu, \%10'u olumsuz, \%14'ü de fikrim yok biçiminde ifade etmiştir.

\section{Öğretmen Adaylarının Düşünce Özgürlüğü Konusundaki Düşünce ve Yaklaşımları}

Düşünce özgürlüğü kavramı, düşünme eyleminin engellenmemesi, düşüncenin açıklanabilmesi ve açıklanan düşünceye herkesin erişebilmesi adımlarını kapsamaktadır. Ankete katılan öğretmen adaylarına "düşünce özgürlüğü kavramından ne anlıyorsunuz?" sorusu yöneltilmiştir.

Tablo II. Öğretmen Adaylarının Düşünce Özgürlüğü Tanımları

\begin{tabular}{lr}
\hline Düşünce özgürlüğü kavramından ne anlıyorsunuz? & Sayı - \%* \\
\hline Herkesin istediği düşünceyi açıklayabilmesi & 68 \\
Herkesin istediği düşünceye sahip olması & 58 \\
Düşüncelerin ülkenin genel düzenine zarar vermeden açıklanması & 49 \\
Herkesin istediği düşünceye erişebilmesi & 28 \\
Diğer & 7 \\
\hline
\end{tabular}

${ }^{*} B u$ soru, birden fazla seçeneğin işaretlenebilmesine olanak tanıyan bir sorudur bu nedenle Tablo II'de sunulan verilerin toplamı 100 olmamaktadır.

Tablo II verilerine göre, öğretmen adaylarının büyük bir bölümü (\% 68) düşünce özgürlüğünü "herkesin istediği düşünceyi açıklayabilmesi” biçiminde tanımlamıştır. "Herkesin istediği düşünceye sahip olması" ve "düşüncelerin ülkenin genel düzenine zarar vermeden açıklanması", seçenekleri de yüksek oranda işaretlenmiştir. Ancak düşünce özgürlüğünü "herkesin istediği düşünceye erişebilmesi" olarak ifade eden aday sayısı oldukça düşüktür. Ayrıca ankete katılan öğretmen adaylarının bir kısmı (\%7) düşünce özgürlüğü kavramı için aşağıdaki ifadeleri kullanmışlardır:

$\diamond$ İktidara yandaşlık yapılması,

$\diamond \quad$ Kimsenin kendi düşüncesinde olmasını beklememesi,

$\diamond$ Düşüncelerin diğer insanları rahatsız etmeden açıklanması,

$\diamond$ Ülkeye zarar verecek dahi olsa hakların önemli olması,

$\diamond$ İnsanların birbirlerinin haklarına saygı duyarak düşüncelerini açıklaması,

$\diamond$ Başkalarının özgürlüğünü engellememesi,

$\diamond$ Başkalarının haklarına zarar vermeden düşüncelerin açıklanması. 
Öğretmen adaylarına “Düşünce özgürlüğünün bir sınırı olmalı mı? sorusu yöneltilmiş, \%47'si "evet", \%32'si "hayır", \%21'i de "kararsızım" yönünde görüş bildirmiştir.

Düşünce özgürlüğünün sınırları konusunda belirttikleri görüşler ise Tablo III'te sunulmuştur.

Tablo III. Öğretmen Adaylarının Düşünce Özgürlüğü Konusundaki Sınırlılıkları

\begin{tabular}{lr}
\hline Düşünce özgürlüğünün sınırları sizce aşağıdakilerden hangileri olmalıdır ? & Sayı - \% \\
\hline Şiddet kullanmaya teşvik ve tahrik eden fikir ve düşünceler & 63 \\
Ulusal güvenliği tehlikeye düşüren fikir ve düşünceler & 59 \\
Kamu düzenini bozan (rejimi tehdit eden, bölücü vb.) düşünce ve fikirler & 56 \\
Ahlaki yapıyı bozan fikir ve düşünceler & 52 \\
Her hangi bir sınır olması gerektiğini düşünmüyorum & 15 \\
\hline
\end{tabular}

Ankete katılan öğretmen adaylarının büyük çoğunluğu, şiddeti teşvik ve tahrik eden düşünceler, ulusal güvenliği ve kamu düzenini bozan düşünceler ile ahlaki yapıyı bozan düşüncelere sınır getirilmesi gerektiği yönünde görüş bildirmişlerdir. Herhangi bir sınır olması gerektiğini düşünmeyenlerin oranı ise \%15'tir. Düşünce özgürlüğüne bazı hukuksal sınırlamalar konulabileceği gerçeğine karşın, burada oranların oldukça yüksek oluşu öğretmen adaylarının sansüre eğilimli olabilecekleri biçiminde yorumlanabilir. Özellikle öğretmen adaylarının yarıdan fazlasının ahlaki nedenlerle bu sınırlamaları kabul etmesi dikkat çekicidir.

Sansür uygulaması yapılması gereken konular ile ilgili görüşleri ise Tablo IV'teki gibidir.

Tablo IV. Öğretmen Adaylarının Sansür Uygulamasına İlişkin Görüşleri

\begin{tabular}{lr}
\hline $\begin{array}{l}\text { Aşağıda belirtilen seçeneklerden hangisi ya da } \\
\text { hangilerine sansür uygulanmasını uygun buluyorsunuz? }\end{array}$ & Sayı - \% \\
\hline Hiçbir konuda sansür uygulamasını uygun bulmuyorum & 48 \\
Ahlaki yapıyı eleştiren yayın ve düşüncelere & 37 \\
Toplum değerlerini eleştiren yayın ve düşüncelere & 25 \\
Genel devlet düzenini eleştiren yayın ve düşüncelere & 17 \\
\hline
\end{tabular}

Ankete katılan öğretmen adaylarının yarıya yakını (\%48) hiçbir konuda sansür uygulamasını uygun bulmamaktadır. Ahlaki yapıyı eleştiren yayın ve düşüncelere sansür uygulamasını uygun bulan öğretmen adaylarının oranı da (\%37) yüksektir. Tablo III ve Tablo IV verileri birlikte değerlendirildiğinde, öğretmen adaylarının düşünce özgürlüğü konusundaki sınırlılıklar ile sansür arasındaki ayrımın farkında oldukları gözlemlenmiştir. Söz konusu tablolarda benzer görünen kavramlara ilişkin oran farklılıklarının bu durumdan kaynaklandığı düşünülebilir. 
Öğretmen adaylarının düşünce özgürlüğü konusundaki tutum ve yaklaşımlarını belirlemek için sorulan bir diğer soru da zararlı ya da yasaklanması gereken düşünceleri çağrıştıran sözcükleri belirlemeye yöneliktir. İlgili veriler Tablo V'te verilmiştir.

Tablo V. Zararlı ya da Yasaklanması Gereken Düşünceleri Çağrıştıran Sözcükler

\begin{tabular}{lr}
\hline Aşağıdaki sözcüklerden hangisi ya da hangileri size zararlı & Sayı \\
ve yasaklanması gereken düşünceleri çağrıştırmaktadır? & $-\%$ \\
\hline Hakaret, küfür, aşağılama & 71 \\
Irkçılık-faşizm & 66 \\
Şiddet & 62 \\
Ateizm & 22 \\
Komünizm & 20 \\
Din & 7 \\
Hiçbiri & 7 \\
Laiklik & 6 \\
\hline
\end{tabular}

Tablo V'te görüldüğü üzere öğretmen adaylarına göre, zararlı ya da yasaklanması gereken düşünceleri çağrıştıran sözcüklerin başında \%71'lik oranla "hakaret, küfür, aşağılama" gelmektedir. Bunu "ırkçılık-faşizm" (\%66) ve "şiddet" (\%62) takip etmektedir. İnanç ve siyasi içerikli sözcüklere ise kısmen hoşgörülü baktıkları söylenebilir.

"Ülkemizde düşünce özgürlüğü olduğuna inanıyor musunuz?" sorusu öğretmen adaylarına yöneltilmiş; \%41'i ülkemizde düşünce özgürlüğü olmadığını, \%50'si belli bir düzeye kadar düşünce özgürlüğü olduğunu, \%9'u ise tam anlamılla düşünce özgürlüğü olduğunu belirtmiştir.

\section{Öğretmen Adaylarının Düşünce Özgürlüğü ile İlgili Tutumlarına Üniversite Eğitiminin Etkisi}

Bireylerin tutumlarını belirleyen birçok etmenin varlığından, bu etmenlerden birinin de alınan eğitim olduğundan yukarıda bahsedilmişti. Yeni nesillerin yetişmesinde büyük görev ve sorumluluk taşıyan öğretmen adaylarına verilen eğitimin ayrıca önemsenmesi gerekmektedir. Bu bölümde, ankete katılan öğretmen adaylarının üniversite eğitimi sırasında düşünce özgürlüğü konusunda ne ölçüde bilinçlendirildiği ile ilgili bulgular değerlendirilmiştir.

Öğretmen adaylarına "Üniversite eğitiminiz sizde düşünce özgürlüğü konusunda farkındalık ve sorumluluk yarattı mı?" sorusu yöneltilmiştir. Elde edilen veriler Tablo Vl'da sunulmuştur. 
Tablo VI. Üniversite Eğitiminin Düşünce Özgürlüğü Konusuna Etkisi

\begin{tabular}{lrr}
\hline $\begin{array}{l}\text { Üniversite eğitiminiz sizde Dö konusunda } \\
\text { farkındalık ve sorumluluk yarattı mı? }\end{array}$ & $\begin{array}{r}\text { Farkındalık } \\
\text { Sayı - \% }\end{array}$ & $\begin{array}{r}\text { Sorumluluk } \\
\text { Sayı - \% }\end{array}$ \\
\hline Evet & 63 & 55 \\
Hayır & 15 & 15 \\
Kısmen & 22 & 30 \\
\hline Toplam & $\mathbf{1 0 0}$ & $\mathbf{1 0 0}$ \\
\hline
\end{tabular}

Ankete katılan öğretmen adaylarının yarıdan fazlası, üniversite eğitiminin düşünce özgürlüğü konusunda farkındalık (\%63) ve sorumluluk (\%55) yarattığını belirtmişlerdir. Diğer yarısının bu konudaki farkındalık ve sorumluluk eksikliklerinin ileride yetiştirecekleri öğrencilere olumsuz yansıması olacağı söylenebilir.

Bilindiği üzere, tutum yalnızca farkındalık ve sorumluluktan oluşmaz. Onun, duygu, düşünce ve davranış boyutları bulunmaktadır. Farkındalık tutumun başlangıç aşaması olabilir; sorumluluk daha farklı ele alınması gereken bir durumdur. Bu nedenle, bir sonraki tabloda (Tablo VII) doğrudan öğrencilerin düşünce özgürlüğü konusundaki tutumlarında üniversite eğitiminin etkisi öğrenilmeye çalışılmıştır. Öğrencilerin, üniversite eğitimleri sırasında düşünce özgürlüğü ile ilgili tutumlarında bir değişiklik olup olmadığı ile ilgili veriler Tablo VII'de verilmiştir.

Tablo VII. Üniversite Eğitiminin Düşünce Özgürlüğü Konusundaki Tutum Üzerine Etkisi

\begin{tabular}{lr}
\hline $\begin{array}{l}\text { Üniversite eğitimi sizin düşünce özgürlüğü } \\
\text { konusundaki tutumunuzu nasıl değiştirdi? }\end{array}$ & Sayı - \% \\
\hline Daha hoşgörülü bakmaya başladım & 66 \\
Bir değişiklik olmadı & 22 \\
Daha katı bakmaya başladım & 8 \\
Fikrim yok & 4 \\
\hline Toplam & $\mathbf{1 0 0}$ \\
\hline
\end{tabular}

Ankete katılan öğretmen adaylarının çoğunun düşünce özgürlüğü konusundaki tutumlarına üniversite eğitiminin olumlu etki yaptığı görülmektedir. Öğretmen adaylarının \%66'sı düşünce özgürlüğü konusuna daha hoşgörülü bakmaya başladığını ifade etmiştir. Ancak beş öğrenciden birisinin bu konuda bir değişiklik yaşamamış olması olumsuz bir durum olarak görülebilir.

İleride yetiştirecekleri öğrencilerde düşünce özgürlüğü ile ilgili tutum oluşturmak amacıyla neyi nasıl yapacakları konusunda, öğretmen adaylarına verilen üniversite eğitiminin etkisini belirlemek amacıyla sorulan soruya verilen yanıtlar Tablo VIII'de görülmektedir. 
Tablo VIII. Düşünce Özgürlüğü Konusunda Üniversite Eğitiminin Bilgilendirme Düzeyi

\begin{tabular}{lr}
\hline ileride öğrencilerinizde düşünce özgürlüğü konusunda tutum oluştururken neyi & \multicolumn{1}{l}{ Sayı - \% } \\
nasıl yapacağınız konusunda üniversite eğitiminiz sizi ne kadar bilgilendirdi? & 17 \\
\hline Tam anlamıyla bilgilendirdi & 63 \\
Kısmen & 20 \\
Hiç & $\mathbf{1 0 0}$ \\
\hline Toplam
\end{tabular}

Ankete katılan öğretmen adaylarının ifadelerine göre, üniversite eğitimleri sırasında düşünce özgürlüğü öğretimi ile ilgili çok düşük düzeyde bir bilgilendirme yapıldığı anlaşılmaktadır.

Tablo VI,VII ve VIII verilerine göre, üniversite eğitiminin, öğretmen adaylarını düşünce özgürlüğü konusunda yeterince bilinçlendirmediği görülmektedir. Bu konudaki eksikliklerin ders programları aracılığı ile giderilmesi önemlidir.

Yaşanan deneyimlerin bireylerde tutum oluşumuna neden olduğu bilinmektedir. Bu amaçla, üniversite eğitimi sırasında öğretmen adaylarının düşünce özgürlüğüne uygun olmayan davranış ve uygulamalara maruz kalıp kalmadıkları araştırılmış ve iki soruyla belirlenmeye çalışılmıştır. İlgili veriler Tablo IX'da sunulmuştur.

Tablo IX. Üniversite Eğitimi Sırasında Düşünce Özgürlüğü'ne Uygun Olmayan Davranışlar

\begin{tabular}{lcc}
\hline & $\begin{array}{c}\text { Üniversite eğitiminiz sırasında düşünce } \\
\text { özgürlüğünüze uygun davranılıor mu? }\end{array}$ & $\begin{array}{c}\text { Üniversite eğitimi sırasında ifade } \\
\text { özgürlüğünüz engellendi mi? }\end{array}$ \\
\hline & Sayı - \% & Sayı - \% \\
Evet & 27 & 33 \\
Hayır & 36 & 33 \\
Kısmen & 37 & 34 \\
\hline Toplam & $\mathbf{1 0 0}$ & $\mathbf{1 0 0}$ \\
\hline
\end{tabular}

Tablo IX verilerine göre, öğretmen adaylarının büyük bir kısmı, üniversite eğitimi sırasında ders işlemleri, ders anlatımı vb. işlemlerde düşünce özgürlüğüne uygun olmayan davranışlara maruz kaldığını belirtmiştir. Yine \%70'e yakın bir kısmı ifade özgürlüğünün tamamen ya da kısmen engellendiğini ifade etmiştir. Yaşanan bu olumsuz deneyimlerin öğretmen adaylarının tutumlarına, dolayısıyla yetiştirecekleri öğrencilerin tutumlarına etki edeceği söylenebilir. 


\section{Öğretmenlerin Yetiştirecekleri Öğrencilerin Düşünce Özgürlüğü Tutumlarına Etkileri Konusundaki Görüşleri}

Bireylerin tutum oluşturmalarına neden olan etmenlerin içinde öğretmenlerin etkisinden daha önce söz edilmişti. Bu bölümde, ankete katılan öğretmen adaylarının ileride yetiştirecekleri öğrencilerin düşünce özgürlüğü tutumlarına etkileri konusundaki görüşlerini belirlemek amaçlanmıştır.

Öğrencilerin ele alınan konudaki yaklaşımlarına, öğretmenlerin ne ölçüde etki edeceği kendilerine sorulmuş ve ilgili veriler Tablo X'da verilmiştir.

Tablo X. Öğretmenlerin Düşünce Özgürlüğü Konusunda

Öğrencilerinin Tutumlarına Etkileri

\begin{tabular}{lr}
\hline $\begin{array}{lr}\text { Sizin şu anki tutumlarınız yetiştireceğiniz öğrencilerin düşünce } \\
\text { özgürlüğü konusundaki tutumlarını belirler mi /etkiler mi? }\end{array}$ & Sayı - \% \\
\hline Evet & 56 \\
Kısmen & 28 \\
Hayır & 14 \\
Fikrim yok & 2 \\
\hline Toplam & $\mathbf{1 0 0}$ \\
\hline
\end{tabular}

Tablo X'da görüldüğü üzere öğretmen adaylarının yarıdan fazlası (\%56) ileride yetiştirecekleri öğrencilerin düşünce özgürlüğü tutumlarında etkili ve belirleyici rol oynayacaklarını düşünmektedirler. Diğer kısmının ise bu konudaki farkındalıklarını artırmak gerekmektedir.

Öğretmen adaylarının, ileride yetiştirecekleri öğrencilerin düşünce özgürlüğü konusunda olumlu tutumlara sahip olması konusundaki düşünceleri ise Tablo Xl'de sunulmuştur.

Tablo XI. Yetiştirecekleri Öğrencilerin Düşünce Özgürlüğü konusunda Olumlu Tutumlara Sahip Olmalarının Önemi

\begin{tabular}{lr}
\hline $\begin{array}{l}\text { Yetiştireceğiniz öğrencilerin düşünce özgürlüğü konusunda } \\
\text { olumlu tutumlara sahip olmaları ne kadar önemlidir? }\end{array}$ & Sayı - \% \\
\hline Çok önemli & 87 \\
Biraz önemli & 6 \\
Önemsiz & 3 \\
Fikrim yok & 4 \\
\hline Toplam & $\mathbf{1 0 0}$ \\
\hline
\end{tabular}


Ankete katılan öğretmen adaylarının büyük çoğunluğu (\%87) yetiştirecekleri öğrencilerin düşünce özgürlüğü konusunda olumlu tutumlara sahip olmalarının "çok önemli" olduğunu ifade etmiştir. Öğretmen adaylarının büyük çoğunluğunun bu konunun önemini kabul etmesi olumlu bir durumdur.

Bu kadar önemli bir konunun bireylere öğretilmesi ise bir başka önemli noktadır. Düşünce özgürlüğü ile ilgili olumlu tutumların geliştirilebilmesi için hoşgörü, bilimsel düşünce, insan haklarına saygı gibi kavramların öğretilmesi gereklidir. Öğretmen adaylarına konu ile ilgili kazandırılması gereken özellikler sorulduğunda Tablo XII'de yer alan veriler elde edilmiştir.

Tablo XII. Düşünce Özgürlüğü Kavramı Öğretilirken Kazandırılması Gereken Kavramlar

\begin{tabular}{lr}
\hline $\begin{array}{l}\text { Sizce düşünce özgürlüğü kavramı öğretilirken aşağıdakilerden } \\
\text { hangisini ya da hangilerini kazandırmak amaç olmalıdır? }\end{array}$ & Sayı - \% \\
\hline Hoşgörü kazandırmak & 81 \\
Insan haklarına saygılı olmayı öğretmek & 76 \\
Bilimsel düşüncenin temellerini kazandırmak & 53 \\
Hepsi (hoşgörü, insan haklarına saygı, bilimsel düşünce) & 45 \\
\hline
\end{tabular}

Öğretmen adaylarının yarıya yakını (\%45) düşünce özgürlüğü kavramı öğretilirken yukarıda belirtilen kavramların hepsinin öğretilmesi gerektiğine inanmaktadır. Diğer kısmı (\%55) ise, düşünce özgürlüğü kavramının öğretilmesinde kazandırılması gereken davranış ve tutumlara değişik yanıtlar vermiştir. Çoğunluğu hoşgörü kazandırmanın (\%81), insan haklarına saygılı olmayı öğretmenin (\%76) ve bilimsel düşünmeyi öğretmenin (\%53) önemli olduğunu belirtmiştir.

\section{Sonuç ve Öneriler}

Hacettepe Üniversitesi İlköğretim Bölümü Sınıf Öğretmenliği Anabilim Dalı 4. sınıfta öğrenim gören 100 öğrenciye uygulanan anket ile öğrencilerin görüşlerine dayalı elde edilen veriler temelinde ulaşılan sonuçları şöyle sıralayabiliriz:

$\diamond$ Öğretmen adayları, düşünce özgürlüğü konusunda tutum geliştirirken en çok ailelerinden arkadaş çevrelerinden ve içinde bulundukları çevreden etkilenmişlerdir. İlk ve ortaöğretim öğretmenlerinden de etkilendiklerini ifade eden öğretmen adayları bulunmaktadır ancak bu oranın azlığı öğretmenlerin bu konudaki sorumluluklarının farkında olmadıklarını ve bu sorumluluklarını yeterince yerine getirmediklerini göstermektedir.

$\diamond$ Düşünce özgürlüğü kavramının istenen düşünceye sahip olma, açıklama ve erişebilmeyi kapsadığı düşünüldüğünde, öğretmen adaylarının büyük çoğunluğunun bu kavram hakkında tam bilgili olmadığı görülmüştür. 
$\diamond$ Öğretmen adaylarının çok az kısmı hiç bir konuda düşünce özgürlüğü sınırlanmamalıdır derken büyük çoğunluğu şiddet kullanmaya teşvik ve tahrik eden, ulusal güvenliği tehlikeye düşüren, kamu düzenini bozan ve ahlaki yapıyı bozan fikir ve düşüncelere sınır getirilmesi gerektiğini düşünmektedir.

$\diamond$ Sansür uygulaması yapılmasını uygun gören ve görmeyen öğretmen adaylarının dağılımı yarı yarıyadır. Öğretmen adaylarına göre, sansür uygulaması yapılması gereken konuların başında ahlaki yapıyı bozan düşünceler gelmektedir. Ayrıca çoğunluğu hakaret, küfür, aşağılama, şiddet, ırkçılık gibi kavramlar söz konusu olduğunda düşünce özgürlüğünün sınırlanması gerektiğini ifade etmiştir. Ateizm ve komünizm gibi inanç ve ideoloji içeren kavramlar söz konusu olduğunda da düşünce özgürlüğünün sınırlanması gerektiğini düşünen öğretmen adayı sayısı azımsanmayacak düzeydedir.

$\diamond$ Üniversite eğitimleri sırasında düşünce özgürlüğü konusunda sorumluluk ve farkındalık kazanan öğretmen adaylarının sayısı yarı yarıyadır. Bu konuda sorumluluk ve farkındalık kazanmayan öğretmen adaylarının eksikliklerinin giderilmesi önemlidir. Üniversite eğitimi sırasında öğretmen adaylarının büyük çoğunluğunun, düşünce ve ifade özgürlüğüne uygun olmayan davranışlarla karşılaşması ise son derece olumsuz bir durumdur.

$\diamond \quad$ Illeride yetiştirecekleri öğrencilerin düşünce özgürlüğü konusunda olumlu tutumlara sahip olmalarını öğretmen adaylarının tamamına yakınının önemsemesi olumlu bir sonuçtur ancak kendi tutumlarının öğrencileri üzerinde etkili olacağının farkında olmayan öğretmen adayı sayısı da az değildir.

$\diamond$ Düşünce özgürlüğü kavramı öğretilirken bilimsel düşüncenin temellerini atmak, hoşgörü sahibi olmayı ve insan haklarına saygılı olmayı öğretmek önemlidir. Ankete katılan öğretmen adaylarının yarıya yakınının böyle düşünmesi de olumlu bir sonuçtur.

Elde edilen sonuçlara göre geliştirilebilecek öneriler şu biçimde sıralanabilir;

$\diamond$ Bireylerin tutum oluşumunda etkili olan ailelerin düşünce özgürlüğü konusunda bilinçlendirilmesi önemli bir konudur. Bu bilinçlendirme basın-yayın yoluyla desteklenmelidir. Ebeveynlerin bu konuda bilinçlenerek çocuklarına iyi rol model olmaları, çocuklarını demokratik, hoşgörülü ve saygılı ortamlarda yetiştirmeleri, düşünce özgürlüğü konusunda olumlu tutumlara sahip bireylerin yetişmesi açısından önemlidir.

$\checkmark$ Bireylerin yetişmesinde ve tutumlarının oluşmasında etkili olan öğretmenlere, özellikle üniversite eğitimleri sırasında düşünce özgürlüğü ile ilgili olumlu tutum kazandırılmalı ve bu tutumları ile yetiştirecekleri öğrencilere örnek olacakları fark ettirilmelidir.

$\diamond$ Düşünce özgürlüğü ile ilgili olumlu tutumlara sahip öğretmenler yetiştirebilmek için, demokratik, çağdaş, hoşgörülü ve önyargıdan uzak eğitim programları ve ortamlar sunulmalıdır. 
$\diamond \quad$ Üniversite eğitim programlarına bu konuda ya ayrı bir ders eklenmeli ya da verilen derslerin içinde bu konu mutlaka yer almalıdır.

$\diamond \quad$ Öğretmen adaylarının bu konudaki sorumluluklarının bilincinde hareket etmesi ve bu konuda kendini geliştirmesi önemlidir. Mesleğe başladıklarında sansürcü ve düşünce özgürlüğüne aykırı uygulamalardan uzak durmaları ancak yeterli bilinçlenme ile mümkün olabilir.

Öğretmenlerin, tutum ve davranışları ile model oldukları öğrencilerin hayatındaki yeri ve etkisi yadsınamaz. Böyle bir etki yapan ve bir ülkenin geleceği olan çocukların eğitiminde görev alan öğretmenlerin yetiştirilmesinde rol alan ailelere, eğitim kurumlarına ve öğretmen adaylarının kendilerine büyük sorumluluklar düşmektedir.

\section{Kaynakça}

Açık Öğretim Fakültesi (AÖF). (2012). E-Öğrenme Eğitim Portalı. 21 Şubat 2013 tarihinde http:// notoku.com/tutum-kavrami-ve-onemi/ adresinden erişildi.

Araslı, O. (1995). Anayasa hukuku açısından düşünce özgürlüğü. M.M.Doğan (haz.). Düşünceye saygı: Düşünce özgürlüğü konuşmaları içinde (s.18-23) Ankara: Edebiyatçılar Derneği.

Avrupa İnsan Hakları Sözleşmesi (AiHS). (1950). 3 Mayıs 2012 tarihinde http://www.todaie.gov.tr/ ihadm/avrupa/aihs.pdf adresinden erişildi.

Besimoğlu, C. ve Korkut, Ş. (2011). Kamu Yönetimi ve Siyaset Bilimi öğrencilerinin düşünce özgürlüğü konusundaki görüşleri üzerine bir araştırma. Türk Kütüphaneciliği, 25(2), 205-237.

Bilal, G. (1984). Demokratik ve otoriter olarak algılanan ana-baba tutumlarının çocukların uyum düzeylerine etkisi. Yayımlanmamış doktora tezi, Hacettepe Üniversitesi, Ankara.

Birleşmiş Milletler. (1948). İnsan Hakları Evrensel Beyannamesi (1949, 27 Mayıs). T.C. Resmi Gazete, 7217.

Demirbolat, A. O. (1999). Demokrasi ve demokratik eğitim. Kuram ve Uygulamada Eğitim Yöntemi Dergisi, 18, 229-244.

Deniz, S. (2000). İlköğretim dönemindeki çocukların yeni davranışlar kazanmalarında tutumların öğrenilmesi ve öğretmenin rolü. Muğla Üniversitesi SBE Dergisi, 1(2), 1-5.

Erdoğan, M. (2007). İfade özgürlüğü ve sınırları. T. Bora (ed.). Ifade özgürlüğü: Ilkeler ve Türkiye içinde (s.19-37). İstanbul: Illetişim Yayınları.

Gömleksiz, M. (1988). Demokratik bir sınıf ortamı açııından Hacettepe Üniversitesi Eğitim Fakültesi öğretim elemanları ve öğrencilerinin davranışlarının değerlendirilmesi. Yayımlanmamış yüksek lisans tezi, Hacettepe Üniversitesi, Ankara.

Gülle, M. T. (1997). Türkiye'de düşünce özgürlüğü sorunu ve halk kütüphanelerine yansıması. Yayımlanmamış doktora tezi, Hacettepe Üniversitesi, Ankara.

Günalp, A. (2007). Farklı anne baba tutumlarının okul öncesi eğitim çağındaki çocukların özgüven duygusunun gelişimine etkisi (Aksaray ili örneği). Yayımlanmamış yüksek lisans tezi, Selçuk Üniversitesi, Konya. 
İflazoğlu, A. ve Çaydaş, E. (2004). Sınıf Öğretmenliği Anabilim Dalında okuyan birinci sınıf öğrencileri ile dördüncü sınıf öğrencilerinin demokratik tutumları ile otoriteryen tutumları arasındaki ilişkinin incelenmesi. XIII. Ulusal Eğitim Bilimleri Kurultayı, 6-9 Temmuz, Malatya: İnönü Üniversitesi.

İnam, A. (1995). Özgür düşünmenin unutulan anlamları. M.M.Doğan (haz.). Düşünceye saygı: Düşünce özgürlüğü konuşmaları içinde (s.15-17). Ankara: Edebiyatçılar Derneği.

İnceoğlu, M. (2010). Tutum algı iletişim. İstanbul: Beykent Üniversitesi.

Kağıtçıbaşı, Ç. (2010). Günümüzde insan ve insanlar: Sosyal psikolojiye giriş. İstanbul: Evrim Yayınevi.

Kızılkan, Z. (1988). Düşünce özgürlüğü ve kütüphanecilik. Türk Kütüphaneciliği, 2(4), 159-165.

Sağlamtunç, T. (1991). Kütüphanecilik açısından düşünce özgürlüğü ve sansür. Türk Kütüphaneciliği, 5(3), 93-99.

Savaş, T. (1995). Açılış konuşması. M.M. Doğan (haz.). Düşünceye saygı: Düşünce özgürlüğü konuşmaları içinde (s.7-9). Ankara: Edebiyatçılar Derneği.

Onaran, M.Ş. (1995). Sunuş konuşması. M.M.Doğan (haz.). Düşünceye saygı: Düşünce özgürlüğü konuşmaları içinde (s.10-12). Ankara: Edebiyatçılar Derneği.

Türk Dil Kurumu (2012). Güncel Türkçe sözlük. 3 Mayıs 2012 tarihinde http://tdkterim.gov.tr/bts/ adresinden erişildi.

Türkiye Büyük Millet Meclisi (TBMM). (1982, 9 Kasım). 1982 Anayasası. T.C. Resmi Gazete, 17863 Mükerrer.

Türkiye Büyük Millet Meclisi (TBMM). (2001, 17 Ekim). Türkiye Cumhuriyeti Anayasasının Bazı Maddelerinin Değiştirilmesi Hakkında Kanun. T.C. Resmi Gazete, 24556.

Yılmaz, K. (2009). Sınıf öğretmenlerinin demokratik tutumlarının algıladıkları anne baba tutumlarına ve bazı demografik değişkenlere göre incelenmesi. Yüksek lisans tezi, Maltepe Üniversitesi, İstanbul. 